\title{
Review
}

\section{Emma Goldman: Political thinking in the streets}

\author{
Kathy E. Ferguson \\ Rowman \& Littlefield, Lanham, MD, 2011, xii +349pp., Hardback: \\ $\$ 60.00 / € 39.95$, ISBN: 978-0742523005
}

Contemporary Political Theory (2013) 12, e8-e10. doi:10.1057/cpt.2012.7

Until fairly recently the tendency among many, if not most, political theorists has been to dismiss anarchist theory as an 'oxymoron', anarchism having long been deemed unworthy of serious scholarly attention. As Paul McLaughlin writes:

\begin{abstract}
According to the academic stereotype, anarchism is theoretically nugatory. Anarchists, it appears, reject the theoretical enterprise as a whole, considering all intellectual activity distracting or even reactionary. Hence there is a lack of anything like an adequate theoretical formulation (if one were even conceivable). Anarchism then, is all about instinctive rebellion - understandable and occasionally justified and illuminating, perhaps, but ultimately irresponsible, immature, and unrealistic - and therefore better suited to popular youth culture than refined academic circles. $(2007$, p. 13)
\end{abstract}

Over the course of the past decade there has been a veritable explosion of academic interest in anarchism. The proliferation of new research on anarchism and the growth of anarchist studies as a distinct scholarly field have done much to combat the longstanding prejudices described above. Kathy Ferguson's Emma Goldman: Political Thinking in the Streets contributes mightily to this effort but also provides a magisterial contribution to political theory in its own right.

As Ferguson rightly notes in her introduction, even sympathetic commentators on Emma Goldman 'seldom apprehend her as a political thinker. Instead, attention has been deflected to her political activism (often defined in opposition to theorizing) or her sexuality' (p. 2). Indeed, this has been the common fate of most thinkers in the anarchist tradition, men and women alike. Although much work has been done in the anarchist studies milieu that seeks to read the classical anarchists as political theorists, it has tended to do so by

(C) 2013 Macmillan Publishers Ltd. 1470-8914 Contemporary Political Theory Vol. 12, 2, e8-e10 www.palgrave-journals.com/cpt/ 
refusing to take them seriously on their own terms. Ferguson does not make this mistake; she does not condescend to Goldman but seeks genuinely to occupy her world and let that world speak for itself.

For Ferguson, the 'academic stereotypes' leveled at Goldman and other anarchists rely on an 'implicit dualism between theory and practice' (p. 5). If we understand political theory as a 'systematic, abstract philosophy integrating metaphysical, epistemological and political questions into a coherent whole', then Goldman cannot be understood as a political theorist - but then, neither can Machiavelli, Kierkegaard, Nietzsche and Benjamin. This suggests that there are different ways of doing political theory, some of which are so intimately linked to practice as to collapse the 'theory/practice dyad' altogether. In Emma Goldman, Ferguson conceptualizes one such alternative view of political theory, one 'that is specifically located in a radical space, articulated passionately amidst intense personal relationships in response to an immediate set of questions about oppressions and possibility' (p. 5). It is just this kind of political thinking that Ferguson attributes to Goldman and to anarchists more generally.

As the subtitle of the book suggests, Goldman's political thinking is 'situated, event-based and concrete'; it takes place in what Ferguson calls 'a located register' (p. 6). For Goldman, political thinking and political acting are reciprocal and symbiotic. They are not 'separate political moments' but mutually produced and mutually producing processes that emerge most clearly and fruitfully when she is 'thinking in the streets, immersed in ongoing struggles, talking them over with friends and comrades, reflecting on their dynamics and possibilities'. This touches upon a distinctive theme in history of anarchism, viz. the hypostatic unity of means/ends and theory/practice. Using Goldman's work as an anarchist writer, orator and organizer (inter alia) as her examples, Ferguson offers a deep analysis of this crucial component of anarchist theory.

Ferguson also situates Goldman's political thinking, and anarchist theory more generally, in what she calls 'the borderland of thought' - a term she borrows from Chesterton:

... We might think of Goldman's as ectopic political theory, theory that is 'out of place'. Here we can come back to the earlier mentioned labor of housekeeping and cooking, along with other labor such as that of striking workers, defiant political prisoners, rebellious playwrights, and unconventional women. Goldman's political thinking encourages us to imagine, not only universities and the libraries of advisors to those who rule, but union halls, kitchens, neighborhoods, unemployment lines, prisons, brothels and other less conventional sites as spaces of political thinking. British writer G.K. Chesterton, in his intriguing 1908 novel about anarchists and government spies, The Man Who Was Thursday, 
portrayed anarchism as 'the borderland of thought'. ... Anarchists disrupt the relation between those who rule and those who are ruled, not by switching places but by opting out of the relationship entirely. (p. 6)

Anarchist theory emerges not only coextensively with anarchist practice, but precisely from those places where political theory is not conventionally understood to be 'done', that is, from the unimportant and invisible spaces where the 'unqualified' (those who lack 'the usual credentials to speak authoritatively, such as a governmental or academic post') act to make their opinions 'become important and to materialize, take shape in space, reconfigure zones of perception in order to give rise to a new shared world' (p. 6). It contests the very hegemonies of 'qualification', which would banish it from scholarly discourse.

Perhaps the most remarkable feature of this book is the extent to which Ferguson brings contemporary critical theory to bear on Goldman's ideas without doing injustice to their native historical, social, cultural and political context. Ferguson believes that '[p]olitical theory does its work by putting an event or idea into a different language, conceptualizing it outside the given dimensions in which the idea or event initially appeared so as to highlight new possibilities for thinking its significance' (p. 7). At the same time, she clearly recognizes that events or ideas must first be understood in their 'initial formats' and 'prevailing contexts' before they can become the staging grounds for more probing theoretical investigations. As noted previously, Ferguson takes anarchist history seriously and is willing to approach Goldman on her own terms before applying the tools of critical theory.

In sum, Emma Goldman: Political Thinking in the Streets is a great achievement and is highly recommended both for scholars of anarchism and for political theorists. For the former, Ferguson provides a fresh and thoughtprovoking analysis of anarchist theory in general and Emma Goldman's political career in particular. For the latter, she offers a novel critique of theory/practice dualism, which has underwritten so much of the academic prejudice toward anarchism.

\section{Reference}

Mclaughlin, P. (2007) Anarchism and Authority. Aldershot, UK: Ashgate.

Nathan J. Jun

Midwestern State University Wichita Falls, TX76308, USA nathan.jun@mwsu.edu 